JEVTE: Journal of Electrical Vocational Teacher Education, Vol. 1, No. 1, Mei 2021

\title{
PENGARUH MODEL PEMBELAJARAN THINK PAIR SHARE (TPS) TERHADAP HASIL BELAJAR DASAR LISTRIK DAN ELEKTRONIKASISWA KELAS X TEKNIK INSTALASI TENAGA LISTRIK (TITL) DI SMKS IMELDA MEDAN
}

\author{
Ita Maruli Simanjuntak ${ }^{1}$, Arif Rahman ${ }^{2}$ \\ Jurusan Pendidikan Teknik Elektro, Fakultas Teknik Universitas Negeri Medan \\ 1simanjuntakithamaruli@gmail.com
}

\begin{abstract}
This study aims to find out the results of basic electrical and electronic learning taught using think pair share learning model and expository learning strategy in students of grade X SMKS Imelda Medan. The method of selecting research samples uses random sampling. The process of collecting data using the test method, namely the collection of final test data (posttest) after treatment. The number of samples per class as many as 60 people. The results of the data analysis with an acceptance rate of 5\% significance showed that the learning outcomes of students who were taught using the think pair share learning model were higher than the learning outcomes of students taught using the expository learning model, where thitung > ttabel, which is 4,050 > 1,677. From the calculation obtained so that the conclusion that the basic learning results of Electricity and Electronics students are taught using the learning model Think Pair Share higher than students who are taught by using the model of expository learning class X Electrical Installation Techniques Private Vocational School Imelda Medan.
\end{abstract}

\section{Keywords: Think Pair Share (TPS) Learning Model, Learning outcomes}

\begin{abstract}
Abstrak
Penelitian ini bertujuan untuk mengetahui hasil belajar Dasar Listrik dan Elektronika yang diajar dengan menggunakan model pembelajaran think pair share dan strategi pembelajaran ekspositori pada siswa kelas X SMKS Imelda Medan. Metode pemilihan sampel penelitian menggunakan random sampling. Proses pengumpulan data menggunakan metode tes, yaitu pengumpulan data tes akhir (posttest) setelah diberikan perlakuan (treatment). Jumlah sampel tiap kelas sebanyak 60 orang. Hasil analisis data dengan tingkat penerimaan pada taraf signifikansi 5\% menunjukkan bahwa hasil belajar siswa yang diajar menggunakan model pembelajaran think pair share lebih tinggi dari hasil belajar siswa yang diajar dengan menggunakan Model pembelajaran ekspositori, dimana thitung > ttabel, yaitu 4,050 > 1,677. Dari perhitungan diperoleh sehingga diperoleh kesimpulan bahwa Hasil belajar Dasar Listrik dan Elektronika siswa yang diajarkan dengan menggunakan model pembelajaran Think Pair Share lebih tinggi dibandingkan siswa yang diajarkan dengan menggunakan model pembelajaran ekspositori kelas X Teknik Instalasi Tenaga Listrik SMK Swasta Imelda Medan.
\end{abstract}

Kata kunci: Model Pembelajaran Think Pair Share (TPS), Hasil belajar

\section{PENDAHULUAN}

Pendidikan adalah usaha untuk mengembangkan potensi Sumber Daya Manusia (SDM) melalui kegiatan pembelajaran. Pendidikan dapat dimaknai sebagai proses mengubah tingkah laku peserta didik agar menjadi manusia dewasa yang mampu hidup mandiri dan sebagai anggota masyarakat dalam lingkungan alam sekitar dimana individu itu berada. Pendidikan tidak hanya mencakup pengembangan intelektualitas saja, akan tetapi lebih ditekankan pada proses pembinaan kepribadian peserta didik secara menyeluruh sehingga peserta didik menjadi lebih dewasa. Dalam dunia pendidikan, keberhasilan dalam pembelajaran ditentukan dengan kualitas dan mutu pendidikan, khususnya di sekolah.

Pendidikan yang diselenggarakan dengan baik dan bermutu akan menghasilkan manusia yang berkualitas dan tangguh bagi pembangunan nasional. Dalam rangka meningkatkan kualitas pendidikan di Indonesia, banyak usaha yang telah dilakukan oleh pemerintah, beberapa di antaranya dengan 
perubahan kurikulum, peningkatan mutu tenaga pendidikan melalui sertifikasi dan penyediaan mediamedia pembelajaran yang bertujuan untuk mengembangkan kualitas peserta didik.

Dalam bidang pendidikan, guru sangatlah berperan dalam merancang dan melaksanakan pembelajaran di dalam kelas, sehingga guru harus mampu menentukan model pembelajaran yang tepat untuk diterapkan. Penentuan model dan media pembelajaran yang akan diterapkan dalam pembelajaran harus disesuaikan dengan materi pelajaran sehingga akan membantu dalam mencapai tujuan pembelajaran secara optimal.

Banyak hal yang mempengaruhi rendahnya hasil belajar siswa. Faktor utama yang memperngaruhi hasil belajar ialah faktor kemampuan siswa dan faktor lingkungan. Menurut Slameto (2016) faktorfaktor tersebut secara global dapat digolongkan menjadi factor internal dan faktor eksternal faktor internal terdiri dari faktor psikologi dan jasmani, sedangkan pada faktor eksternal terdiri dari faktor keluarga, faktor sekolah, dan factor masyarakat. Dari faktor-faktor yang mempengaruhi hasil belajar di atas, faktor eksternal mempengaruhi redahnya hasil belajar yaitu model pembelajaran yang digunakan oleh guru. Guru dituntut untuk menguasai bahan pelajaran yang disajikan, dan memilih model serta media yang tepat dalam mengajar.

Berdasarkan pengalaman magang di SMK Swasta Imelda Medan, guru masih belum menggunakan model pembelajaran yang dapat meningkatkan keterlibatan dan keaktifan siswa. Hal ini terlihat dari proses pembelajaran dan bagaimana cara guru mengajar siswa di dalam kelas yang masih menggunakan model pembelajaran yang berpusat pada guru (Ekspositori). hasil wawancarai yang saya laksanakan di SMK Swasta Imelda Medan pada mata pelajaran dasar listrik dan elektronika didapat bahwa nilai KKM di SMK Swasta Imelda adalah 75. Hasil belajar siswa kelas X Teknik Instalasi Tenaga Listrik (TITL)untuk mata pelajaran Dasar Listrik dan Elektronika diperoleh sebanyak 64\% siswa yang belum memenuhi nilai KKM dan 36\% siswa yang sudah memenuhi nilai KKM. Namun, siswa yang belum mendapat nilai KKM, guru mata pelajaran akan memberikan ujian remedial kepada siswa yang bersangkutan. Ujian Remedial ini diberikan untuk memperbaiki nilai siswa yang tidak mencapai nilai 75.

Pada pembelajaran dengan model Ekspositori, guru lebih dominan jadi pusat perhatian dan siswa kurang dilibatkan dalam aktifitas belajar oleh guru, sehingga siswa kurang mampu untuk mengoptimalkan potensi yang dimilikinya karena cenderung hanya menerima pelajaran, kurang memiliki keberanian dalam menyampaikan pendapat, enggan untuk bertanya bila ada materi yang kurang jelas dan siswa belum terbiasa menyampaikan pendapat kepada orang lain.

Oleh karena itu, untuk meningkatkan kualitas pembelajaran dapat dilakukan dengan inovasi pembelajaran, yaitu menciptakan suatu proses belajar mengajar yang lebih menarik, menyenangkan, dan mudah dipahami oleh siswa dengan menggunakan model pembelajaran yang dapat menarik perhatian siswa sehingga akan meningkatkan hasil belajar. Hal yang diharapkan dapat mengatasi masalah tersebut adalah dengan model pembelajaran kooperatif. Salah satu tipe dari pembelajaran kooperatif adalah Think Pair Share. Menurut Trianto (2014) model pembelajaran Think Pair Share merupakan salah satu bagian dari pembelajaran kooperatif yang sederhana, sehingga cocok diterapkan untuk mata pelajaran Dasar listrik dan elektronika.

Model pembelajaran Think Pair Share dipilih karena model pembelajaran ini memberi kesempatan pada siswa untuk berpikir, menjawab, saling membantu satu sama lain, dan akan menambah variasi model pembelajaran yang lebih menarik, menyenangkan, meningkatkan aktivitas dan kerja sama siswa (Huda, 2012) Penggunaan model Think Pair Share dalam pembelajaran memungkinkan siswa untuk terlibat secara aktif dalam proses pembelajaran karena dilaksanakan dalam kelompok kecil dan berpasangan sehingga memberi siswa kesempatan untuk bekerja sendiri serta bekerja sama dengan orang lain.

Berdasarkan uraian di atas, dilakukan penelitian dengan judul "Pengaruh Model Pembelajaran Think Pair Share (TPS) Terhadap Hasil Belajar Dasar Listrik dan Elektronika Siswa Kelas X Teknik Instalasi Tenaga Listrik (TITL) di SMKS Imelda Medan".

\section{Hakekat Hasil Belajar}

Belajar merupakan proses manusia untuk mencapai berbagai macam kompetensi, keterampilan, dan sikap. Hasil belajar merupakan nilai yang diperoleh siswa melalui tes evaluasi setelah proses belajar 
mengajar dilakukan. Usaha untuk mencapai kepandaian atau ilmu merupakan usaha manusia untuk memenuhi kebutuhannya, mendapatkan ilmu atau kepan daian yang belum dipunyai sebelumnya.Sehingga dengan belajar manusia menjadi tahu, memahami, mengerti, dapat melaksanakan dan memiliki tentang sesuatu. Dari defenisi ini dimensi belajar memuat beberapa unsur, yaitu: (1) penciptaan hubungan, (2) sesuatu hal (pengetahuan), dan (3) sesuatu (pengetahuan) yang baru. Jadi, dalam makna belajar disini bukan berangkat dari sesuatu yang benar-benar belum diketahui (nol), tetapi merupakan keterkaitan dari dua pengetahuan yang sudah ada dengan pengetahuan baru. Dalam keseluruhan proses pendidikan di sekolah kegiatan belajar mengajar merupakan kegiatan paling pokok. Hal ini berarti bahwa keberhasilan atau tidaknya pencapaian tujuan pendidikan bergantung pada proses belajar yang dilakukan siswa sebagai anak didik.Slameto (2003:13) menyatakan "belajar merupakan suatu proses usaha yang dilakukan seseorang untuk memperoleh suatu perubahan tingkah laku yang baru secara keseluruhan, sebagai hasil pengalamannya sendiri dalam interaksi dengan lingkungannya". Untuk mendapatkan sesuatu seseorang harus melakukan usaha agar apa yang di inginkan dapat tercapai.

Usaha tersebut dapat berupa kerja mandiri maupun kelompok dalam suatu interaksi. Belajar merupakan suatu proses usaha yang dilakukan oleh seseorang untuk memperoleh suatu perubahan yang baru sebagai hasil pengalamannya sendiri dalam interaksi dengan lingkungannya. Belajar berhubungan dengan perubahan tingkah laku seseorang terhadap sesuatu situasi tertentu yang disebabkan oleh pengalamannya yang berulang-ulang dalam suatu situasi. Menurut Soedijarto (2016) bahwa, "hasil belajar adalah tingkat penguasaan yang dicapai oleh pelajar dalam mengikuti program belajar mengajar sesuai dengan tujuan pendidikan yang ditetapkan". Sedangkan Jika hakikat belajar adalah perubahan tingkah laku, maka ada beberapa perubahan tertentu yang dimasukkan ke dalam ciri-ciri belajar menurut Djamarah (2002:15-16) sebagai berikut :

1. Perubahan yang terjadi secara sadar Individu yang belajar akanmenyadari terjadinya perubahan atau sekurang - kurangnya individu merasakan telah terjadi adanya suatu perubahan dalam dirinya.

2. Perubahan dalam belajar bersifat fungsional sebagai hasil belajar, perubahan yang terjadi dalam diri indiviu berlangsung terus-menerus dan tidak statis. Suatu perubahan yang terjadi akan menyebabkan perubahan berikutnya dan akan berguna bagi kehidupan atau proses belajar berikutnya.

3. Perubahan dalam belajar bersifat positif dan aktif Dalam perbuatan belajar, perubahan selalu bertambah dan tertuju memperoleh suatu yang lebih baik dari sebelumnya. Makin banyak usah belajar dilakukan, makin banyak dan makin baik perubahan yang diperoleh.

4. Perubahan dalam belajar bukan bersifat sementara Perubahan bersifat sementara yang terjadi hanya untuk beberapa saat saja seperti berkeringat, keluar airmata, menangis dan sebagainya. Perubahan terjadi karena proses belajar bersifat menetap atau permanen.

5. Perubahan mencakup seluruh aspek tingkah laku Perubahan yang diperoleh individu setelah melalui suatu proses belajar meliputi perubahan keseluruhan tingkah laku jika seseorang belajar sesuatu sebagai hasil ia akan mengalami perubahan tingkah laku secara menyeluruh dalam sikap kebiasaan, keterampilam, pengetahuan.

Dari definisi diatas, maka dapat diambil kesimpulan bahwa hasil belajar adalah kemampuan belajar yang dicapai siswa dalam proses kegiatan belajar mengajar dengan membawa suatu perubahan dan pembentukan tingkah laku seseorang. Untuk menyatakan bahwa suatu proses belajar dapat dikatakan berhasil, setiap guru memiliki pandangan masing-masing sejalan dengan filsafatnya.

Menurut Muhaidi dalam Seri, (2014:10) faktor-faktor yang mempengaruhi hasil belajar yaitu sebagai berikut :

1. Faktor internal merupakan faktor yang berasal dari dalam diri seseorang yang meliputi faktor fisikologis dan faktor psikologis.

2. Faktor eksternal merupakan faktor yang berasal dari luar diri seseorang, yang meliputi faktor lingkungan, dan faktor instrumental. Dari pendapat di atas dapat disimpulkan ada dua faktor yang mempengaruhi hasil belajar yaitu faktor internal yang meliputi: jasmani psikologi, minat, motivasi dan cara belajar. Sedangkan faktor eksternal meliputi : faktor keluarga, sekolah dan masyarakat. 
Hasil belajar menggambarkan pencapaian usaha siswa dalam proses belajar mengajar baik berupa nilai atau point dalam menjawab pertanyaan. Hasil belajar juga merupakan gambaran dari cara belajar siswa dan dapat dilihat dari rapor yang diterima siswa.

\section{Hakekat Dasar Listrik dan Elektronika}

Menguasai dasar kompetensi kejuruan Dasar Listrik dan Elektronika merupakan salah satu standart kompetensi pada kompetensi keahlian teknik instalasi tenaga listrik siswa kelas X (sepuluh) pada semester Genap. Dimana mata pelajaran ini tergolong penting dan membutuhkan pemahaman yang baik sebagai dasar penunjang penyelesaian masalah-masalah yang berhubungan dengan listrik dan elektronika. Namun dalam pelaksanaan proses pembelajaran yang diberikan, ternyata masih terdapat beberapa kendala baik secara internal maupun eksternal. Dasar kopetensi kejuruan Dasar Listrik dan Elektronika sangat berhubungan dengan mata pelajaran lainnya. Oleh karena itu siswa diharapkan dapat menguasai dasar kopetensi kejuruan Dasar Listrik dan Elektronika baik melalui pembelajaran pengetahuan, seperti teori maupun pelajaran keterampilan yaitu praktik.

\section{Hakekat Model Pembelajaran}

Model pembelajaran adalah suatu perencanaan atau suatu polayang digunakan sebagai pedoman dalam merencanakan pembelajaran di kelas atau pembelajaran tutorial dan untuk menentukan perangkat-perangkat pembelajarantermasuk didalamnya buku-buku,film,komputer,kurikulum dan lain lain. Materi belajar pada semester genap yaitu Menganalisis Rangkaian Listrik Arus Searah,berdasarkan opsi tersebut maka hasil belajar dasar listrik dan elektronika dalam penelitian ini adalah penguasaan siswa terhadap materi pelajaran dasar listrik dan elektronika dengan indikatatorMenganalisis Rangkaian Listrik Arus Searah. Adapun hakekat hasil belajar rangkaian arus searah adalah kemampuan memahami hingga menganalisis rangkaianarus searah yang diperoleh siswa setelah menerima/mengikuti pembelajaran rangkaian arus searah tersebut secara khusus pada kompetensi dasar yang bersangkutan.Dalam hal ini kompetensi dasar yang akan diajarkan dalam penelitian ini adalah rangkaian arus searah. Tabel silabus Dasar Listrik dan Elektronika untuk kompetensi dasar rangkaian arus searah dapat dilihat pada lampiran. (Joyce,1992:4).

Seorang guru dalam suatu kegiatan belajar mengajar wajib menyampaikan materi pelajaran sesuai kurikulum yang berlaku sehingga siswa mampu mencapai kompetensi yang telah ditetapkan. Pencapaian kompetensi dapat tercapai apabila guru mampu mengoptimalkan cara belajar mengajar didalam kelas, yaitu dengan menggunakan model-model pembelajaran yang tepat. Istarani (2012:1) menyatakan "Model pembelajaran adalah seluruh rangkaian penyajian materi ajar yang meliputi segala aspek sebelum sedang dan sesudah pembelajaran yang dilakukan guru serta segala fasilitas yang terkait yang digunakan secara langsung atau tidak langsung dalam proses belajar mengajar". Semua rangkaian materi ajar harus meliputi segala aspek dan guru berperan sebagai fasilitator didalam proses belajar mengajar secara langsung maupun tidak langsung.

Suprijono (2012:46) menyatakan bahwa "Model pembelajaran ialah pola yang digunakan sebagai pedoman dalam merencanakan pembelajaran di kelas maupun tutorial “. Joyce \& Weil dalam Rusman,( 2012:133) menyatakan "Model pembelajaran adalah suatu rencana atau pola yang dapat digunakan untuk membentuk kurikulum (rencana pembelajaran jangka panjang), merancang bahan-bahan pembelajaran, dan membimbing pembelajaran di kelas atau yang lain”. Model pembelajaran dijadikan sebagai pedoman untuk merencanakan suatu proses belajar mengajar yang akan dilakukan didalam kelas baik untuk jangka pendek maupun jangka panjang, yang meliputi merancang bahan-bahan pembelajaran, dan membimbing pembelajaran di kelas atau yang lain.

\section{Hakekat Model Pembelajaran Think Pair Share}

Pengertian Think Pair menurut Arends (Trianto, 2007: 121) menyatakan bahwa Think Pair Share merupakan suatu cara yang efektif untuk membuat variasi suasana pola diskusi kelas. Dengan asumsi bahwa semua resitasi atau diskusi membutuhkan pengaturan untuk mengendalikan kelas secara keseluruhan, dan prosedur yang digunakan dalam Think Pair Share dapat memberi siswa lebih banyak waktu berpikir, untuk merespon dan saling membantu. 
Guru memperkirakan hanya melengkapi penyajian singkat atau siswa membaca tugas atau situasi yang menjadi tanda tanya. Suyatno (2009: 54) mengatakan bahwa Think Pair Share adalah model pembelajaran kooperatif yang memiliki prosedur ditetapkan secara eksplinsit memberikan waktu lebih banyak kepada siswa untuk memikirkan secara mendalam tentang apa yang dijelaskan atau dialami (berfikir, menjawab, dan saling membantu satu sama lain)". Secara umum, model Think Pair Shareberisi tiga tahapan sebagaimana yang dikemukakan oleh Lie (2005) yaitu:1) Berpikir (Thinking). Pada tahap ini siswa diminta untuk berpikir secara mandiri mengenai pertanyaan atau masalah yang diajukan. Siswa sebaiknya menuliskan jawaban mereka, sehingga melalui catatan tersebut guru dapat mengetahui jawaban yang harus diperbaiki atau diluruskan diakhir pembelajaran. Dalam menentukan batasan waktu untuk tahapan ini, guru harus mempertimbangkan pengetahuan dasar siswa untuk menjawab pertanyaan yang diberikan, serta jadwal pembelajaran untuk setiap kali pertemuan.

Kelebihan dari tahap ini adalah "think time" atau waktu berpikir yang memberikan kesempatan kepada siswa untuk berpikir mengenai jawaban mereka sendiri sebelum pertanyaan tersebut dijawab oleh siswa lain. Selain itu, guru dapat mengurangi masalah dari adanya siswa yang mengobrol, karena setiap siswa memiliki tugas untuk dikerjakan sendiri, 2) Berpasangan (Pairing). Selanjutnya guru meminta kepada siswa untuk berpasangan.

Model pembelajaran Think Pair Share (TPS) pertama kali dikembangkan oleh Frank Lyman dan Koleganya di Universitas Maryland pada tahun 1985. Shoimin (2014:208) mengungkapkan bahwa, "Model pembelajaran Think Pair Share adalah suatu model pembelajaran kooperatif yang memberi siswa waktu untuk berpikir dan merespons serta saling bantu satu sama lain". Sedangkan Kurniasih dan Berlin (2015:58) mengungkapkan bahwa "Model Pembelajaran Think Pair Share (TPS) atau berpikir berpasangan berbagi adalah jenis pembelajaran kooperatif yang dirancang untuk mempengaruhi pola interaksi siswa". Selanjutnya menurut Arends dalam Istarani, (2014:214) "Model pembelajaran Think Pair Share merupakan suatu cara yang efektif untuk membuat variasi suasana pola diskusi kelas".

Dari beberapa definisi di atas dapat disimpulkan bahwa model pembelajaran Think Pair Share adalah model pembelajaran kooperatif yang berfokus pada diskusi kelompok kecil (berpasangan) yang efektif digunakan untuk memaksimalkan kondisi belajar dan mempengaruhi pola interaksi siswa

\section{Hakekat Model Pembelajaran Ekspositori}

Strategi pembelajaran ekspositori adalah strategi pembelajaran yang menekankan kepada proses penyampaian materi secara verbal dari seseorang guru kepada sekelompok siswa dengan maksud agar siswa dapat menguasai materi pelajaran secara optimal. Roy Killen dalam WinaSanjaya (2006:179). Menamakan strategi ekspositori ini dengan istilah strategi pembelajaran langsung (direct instruction). Karena dalam strategi materi pelajaran disampaikan langsung oleh guru. Siswa tidak dituntut untuk menemukan materi itu. Materi pelajaran seakan-akan sudah jadi. Oleh karena ekspositori lebih menekankan kepada proses bertutur.

Terdapat beberapa karakteristik model ekspositori. Pertama, strategi ekspositori dilakukan dengan cara menyampaikan materi pelajaran secara verbal, artinya bertutur secara lisan merupakan alat utama dalam melakukan strategi ini. Oleh karena itu ekspositori di identikkan dengan ceramah. Kedua, biasanya materi pelajaran yang disampaikan adalah materi pelajaran yang sudah jadi seperti data atau fakta, konsep-konsep tertentu yang harus dihafal sehingga tidak menuntut siswa untuk berpikir ulang.Ketiga, tujuan utama pembelajaran adalah penguasaan materi pelajaran itu sendiri. Artinya, setelah proses pembelajaran berakhir siswa diharapkan dapat memahaminya dengan benar dengan cara dapat mengungkapkan kembali materi yang telah diuraikan.

Strategi pembelajaran ekspositori adalah interaksi antara guru dan siswa dalam rangka pencapaian tujuan pembelajaran.untuk menyampaikan pengetahuan itu kepada siswanya. Tujuan pembelajaran terbatas pada pemilikan ilmu pengetahuan. Oleh karena itu orang yang memiliki banyak ilmu pengetahuan dipandang arif, bijaksana dan pandai.

\section{METODE PENELITIAN}

Penelitian ini akandilaksanakan di SMK Swasta Imelda Medan yang beralamat di Jalan Bilal No.52 Pulo Brayan Darat 1 Medan Timur. Penelitian ini dilaksanakan pada semester Ganjil Tahun Pelajaran 
2019/2020. Sampel dalam penelitian ini diambil menggunakan teknik purposive sampling, sehingga sampel dalam penelitian ini terdiri dari 2 kelas, yaitu kelas X TITL 1 berjumlah 30 siswa sebagai kelas Kontrol dan kelas X TITL 2 berjumlah 30 siswa sebagai kelas Eksperimen. Alasan peneliti mengambil kedua kelas ini adalah karena guru mata pelajaran Dasar Listrik dan Elektronika sama dan hasil belajar kedua kelas tersebut masih tergolong rendah dengan selisih nilai antara kedua kelas tidak terlalu jauh. Dari jumlah 30 siswa diambil dengan teknik purposive sampling secara undian yaitu masing-masing kelas 30 dan 30 siswa, hal ini dilakukan untuk menjaga kehilangan anggota sampel, siswa yang tidak termasuk dalam sampel tetap diperlakukan sama di dalam kelas. Jenis penelitian ini adalah jenis penelitian eksperimen. Yaitu penelitian yang berusaha mengetahui ada tidaknya perbedaan hasil belajar antara dua kelas yang di berikan perlakuan yang berbeda. Dalam pelaksanaan penelitian ini masingmasing kelas di ajarkan dengan materi yang sama dan dengan pengajaran yang berbeda yaitu kelas eskperimen menggunakan model Think Pair Share dan kelas control menggunakan model Ekspositori

Penelitian ini melibatkan dua kelas, dimana keduanya diberikan perlakuan yang berbeda. Model pembelajaran Think Pair Share akan dilakukan di kelas eksperimen dan model Ekspositori dilakukan di kelas kontrol. Berikut langkah - langkah yang ditempuh pada saat penelitian : (a) Persiapan, (b) Validasi, (c) Pemberian Perlakuan, (d) Pelaksanaan Uji Instrumen, (e) Pelaksanaan posttes, (f) Analisis data dan interpretasi hasil.

Dalam penelitian ini, untuk memperoleh data hasil penelitian, peneliti menggunakan teknik analisis data sebagai berikut :(a) nilai rata- rata (Mean), (b) standart deviasi. (c) varians, (d) uji normalitas data, (e) uji homogenitas data, dan (f) pengujian hipotesis.

\section{HASIL DAN PEMBAHASAN}

Berdasarkan tes hasil belajar yang diberikan setelah proses pemberian perlakuan dengan Strategi Pembelajaran Think Pair Share diperoleh rata-rata skor $=86,36$; Varians $=34,30$; Standar Deviasi 5,85 ; skor tertinggi $=97$; skor terendah $=77$ dengan jumlah sample $=30$ orang. Dengan menggunakan teknik sturges didapatkan banyak kelas 6 dan panjang kelas 2,66 maka daftar distribusi frekuensi mengenai hasil belajar yang diajar dengan menggunakan Strategi Pembelajaran Think Pair Share dapat dilihat pada tabel 4.1 dibawah ini:

Tabel 1. Distribusi Frekuensi Skor Hasil Belajar Siswa yang Diajar dengan Menggunakan Strategi

Pembelajaran Think Pair Share

\begin{tabular}{|c|c|c|c|}
\hline \multicolumn{4}{|c|}{ Kelas Eksperimen } \\
\hline Kelas & Interval & Frekuensi & Fr $(\%)$ \\
\hline 11 & $77-79$ & 3 & 10.00 \\
\hline 2 & $80-82$ & 5 & 16,66 \\
\hline 33 & $83-85$ & 4 & 13,33 \\
\hline 44 & $86-88$ & 6 & 20,00 \\
\hline 55 & $89-91$ & 6 & 20,00 \\
\hline 66 & $92-94$ & 4 & 13,33 \\
\hline 77 & $95-97$ & 2 & 16,66 \\
\hline \multicolumn{2}{|c|}{ Jumlah } & 30 & 100 \\
\hline
\end{tabular}

Dari hasil distribusi frekuensi skor hasil belajar siswa yang diajar dengan menggunakan strategi pembelajaran Think Pair Share dapat digambarkan diagram batang distribusi dan dapat dilihat pada Gambar 1 sebagai berikut. 


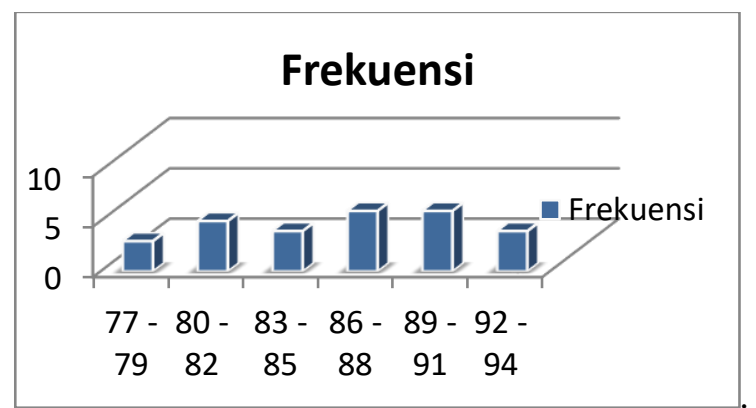

Gambar 1. Diagram Batang Hasil Belajar siswa yang diajar dengan menggunakan Strategi Pembelajaran Think Pair Share

Berdasarkan tes hasil belajar yang diberikan setelah proses pemberian perlakuan dengan menggunakan strategi pembelajaran ekspositori diperoleh rata-rata skor $=77,07$; varians $=46,27$; standar deviasi $=6,80$, skor tertinggi $=90$ dan skor terendah $=67$ dengan jumlah sampel 30 siswa. Dengan menggunakan teknik Sturges didapatkan banyak kelas 6 dan panjang kelas 3,333, maka daftar distribusi frekuensi mengenai hasil belajar yang diajar dengan Strategi pembelajaran ekspositori dapat dilihat pada Tabel 2 dibawah ini :

Tabel 2. Distribusi Frekuensi Skor Hasil Belajar Siswa Yang Diajar Dengan Menggunakan Strategi Pembelajaran Ekspositori

\begin{tabular}{|c|c|c|c|}
\hline \multicolumn{4}{|c|}{ Kelas Kontrol } \\
\hline Kelas & Interval & Frekuensi & $\operatorname{Fr}(\%)$ \\
\hline 1 & $67-70$ & 6 & 20,00 \\
\hline 2 & $71-74$ & 7 & 23,22 \\
\hline 3 & $75-78$ & 4 & 13,33 \\
\hline 4 & $79-82$ & 5 & 16,66 \\
\hline 5 & $83-86$ & 5 & 16,66 \\
\hline 6 & $87-90$ & 3 & 10,00 \\
\hline \multicolumn{2}{|c|}{ Jumlah } & 30 & 100,00 \\
\hline
\end{tabular}

Hasil distribusi frekuensi skor hasil belajar siswa yang diajar dengan menggunakan strategi pembelajaran ekspositori dapat digambarkan diagram batang distribusi dan dapat dilihat pada gambar 2 sebagai berikut.

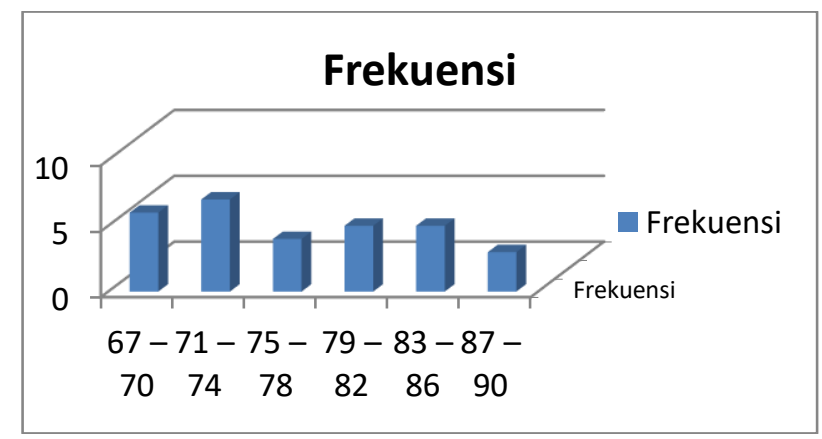

Gambar 2. Diagram Batang Hasil Belajar Siswa yang Diajar dengan Menggunakan Strategi Pembelajaran Ekspositori 
Penelitian yang dilakukan di SMK Swasta Imelda menggunakan sampel dua kelas yaitu X TITL 1 yang diajar dengan menggunakan model pembelajaran Think Pair Share (TPS) dan Kelas XTITL 2 sebagai pengendali yaitu dengan menggunakan model pembelajaran Ekspositori.

Para siswa diberikan pembelajaran dengan perlakuan yang berbeda, pada kelas Think Pair Share (TPS) siswa diberi perlakuan dengan menggunakan model pembelajaran Think Pair Share (TPS) sedangkan pada kelas kontrol siswa diberi perlakuan dengan menggunakan model pembelajaran Ekspositori. Ini membuktikan hasil belajar siswa yang menggunakan strategi pembelajaran Think Pair Share lebih baik dari pada strategi pembelajaran ekspositori, sehingga dapat disimpulkan bahwa terdapat pengaruh penggunaan strategi pembelajaran Think Pair Share terhadap Hasil Belajar Dasar Listrik dan Elektronika pada Siswa Kelas X Teknik Instalasi Tenaga Listrik SMK Swasta Imelda.

Pada akhir pembelajaran dilakukan tes yang hasilnya di analisis untuk mengetahui perbedaan antar kedua kelas. Analisis tahap akhir menunjukkan data hasil belajar kelas eksperimen dan kelas kontrol berdistribusi normal karena Lhitung untuk setiap data kurang dari Ltabel. Berdasarkan uji hipotesis yang telah dilakukan, diperoleh thitung $=4,050$ sedangkan ttable $=1,677$. Karena thitung $>$ ttabel atau berada pada daerah penerimaan Ha maka dapat disimpulkan bahwa Hasil belajar Dasar Listrik dan Elektronika siswa yang diajarkan dengan menggunakan strategi pembelajaran Think Pair Share lebih tinggi dibandingkan siswa yang diajarkan dengan menggunakan strategi pembelajaran ekspositori kelas $\mathrm{X}$ Teknik Instalasi Tenaga Listrik SMK Swasta Imelda. Berbeda halnya dengan penggunaan model pembelajaran Ekspositori. Dengan guru sebagai pengatur utama dalam proses pembelajaran dan siswa hanya sebagai penerima informasi dari guru, dimana guru lebih banyak memberikan penjelasan atau ceramah yang menjadikan siswa pasif. Dengan kata lain proses pembelajaran dengan menggunakan model ini hanya berjalan satu arah.

Dalam penelitian ini, penerapan model pembelajaran Think Pair Share dapat meningkatkan hasil belajar yang lebih tinggi dibandingkan hasil belajar siswa yang diajarkan dengan menggunakan model pembelajaran Ekspositori. Serta Hasil belajar tersebut di uji dengan menggunakan uji-t satu pihak yaitu pihak kanan sehingga hipotesis penelitian Ha diterima. Maka terbukti hasil belajar pada mata pelajaran Instalasi Penerangan Listrik pada siswa yang diajar dengan menggunakan model pembelajaran Think Pair Share (TPS) lebih tinggi daripada siswa yang diajar dengan menggunakan model pembelajaran Ekspositori di Kelas XI TITL SMK Swasta Imelda T.P 2019/2020.

\section{KESIMPULAN}

Berdasarkan hasil penelitian yang diuraikan pada BAB IV, maka diambil kesimpulan sebagai berikut:

1. Hasil belajar Dasar Listrik dan Elektronika siswa yang diajarkan dengan menggunakan strategi pembelajaran Think Pair Share pada siswa kelas X Teknik Instalasi Tenaga Listrik SMK Swasta Imelda cenderung cukup baik hal ini dilihat dari uji kecenderungan variabel penelitian yang memiliki rata - rata 86,37.

2. Hasil belajar Dasar Listrik dan Elektronika siswa yang diajarkan dengan menggunakan strategi pembelajaran ekspositori pada siswa kelas X Teknik Instalasi Tenaga Listrik SMK Swasta Imelda cenderung baik hal ini dilihat dari uji kecenderungan variabel penelitian yang memiliki rata - rata 77,07 .

3. Hasil belajar Dasar Listrik dan Elektronika siswa yang diajarkan dengan menggunakan strategi pembelajaran Think Pair Share lebih tinggi dibandingkan siswa yang diajarkan dengan menggunakan strategi pembelajaran ekspositori kelas X Teknik Instalasi Tenaga Listrik SMK Swasta Imelda. Hal ini dapat dilihat dari hasil belajar Dasar Listrik dan Elektronika siswa yang diajarkan menggunakan strategi pembelajaran Think Pair Share lebih tinggi dari hasil belajar siswa yang diajar dengan menggunakan strategi pembelajaran ekspositori, dimana thitung > ttabel, yaitu 4,050 >1,677.

\section{DAFTAR PUSTAKA}

Arikunto, Suharsimi. (2013). Dasar-Dasar Evaluasi Pendidikan. Jakarta: Bumi Aksara.

Djamarah, Syaiful Bahri dan Aswan Zain. (2013). Strategi Belajar Mengajar. Jakarta: Rineka Cipta. 
Huda, Miftahul. (2012). Cooperative Learning Metode, Teknik, Struktur dan Model Penerapan. Yogyakarta: Pustaka Pelajar.

Istarani. (2014). 58 Model Pembelajaran Inovatif. Medan: Media Persada.

Lubis, Effi Aswita. (2013). Strategi Belajar Mengajar. Medan: Perdana Publishing

Maulia Rizki Pangestika. (2015). Pengaruh Pembelajaran Kooperatif Tipe TPS (Think-Pair-Share) dengan Teknik Power Of Two Terhadap Hasil Belajar Siswa pada Materi Kalor di Kelas X SMA Negeri 1 Bangkalan. Skripsi UNESA.

Nababan Goklas. (2011). Pengaruh Model Pembelajaran Kooperatif Tipe Think Pair Share (TPS) Terhadap Hasil Belajar Memahami Pengukuran Komponen Elektronika Siswa Kelas X SMK N 1 Siborong - Borong Tahun Ajaran 2010/2011. Skripsi UNIMED.

Pane Arif Rahman. (2012). Pengaruh Penerapan Pembelajaran Kooperatif Tipe Think Pair Share (TPS) Terhadap Hasil Belajar Siswa Pada Pokok Bahasan Listrik Statis di Kelas IX SMP N 5. Skripsi UNIMED.

Purwanto. (2014). Evaluasi Hasil Belajar. Yogyakarta: Pustaka Pelajar.

Rika Wulandari. (2015) Pengaruh Model Pembelajaran Kooperatif Tipe Think Pair Share ( TPS ) Terhadap hasil belajar Matematika Siswa Kelas X MIA SMA N 2 Lubuklinggau Tahun Pembelajaran 2014/2015, Skripsi STKIP.

Sanjaya, Wina. (2013). Strategi Pembelajaran Berorientasi Standar Proses Pendidikan. Jakarta: Kencana.

Shoimin, Aris. (2014). 68 Model Pembelajaran Inovatif Dalam Kurikulum 2013. Yogyakarta: Ar-Ruzz Media.

Silitonga, P. (2011). Statistik Teori Dan Aplikasi Dalam Penelitian. Medan : Fakultas Matematika Dan Ilmu Pengetahuan Alam Universitas Negeri Medan

Slameto. (2010). Belajar dan Faktor-faktor yang Mempengaruhinya. Jakarta: Rineka Cipta

Slameto. (2016). Belajar dan faktor-faktor yang mempengaruhi. Jakarta: Rineka Cipta

Sudijono, A. (2008). Pengantar Statistik Pendidikan. Jakarta: Rajagrafindo Persada.

Sudjana. (2005). Metoda Statistika. Bandung : Tarsito Bandung

Sudjana. (2014). Metoda Statistika. Bandung: Tarsito

Susanto, Ahmad. (2014). Teori Belajar Dan Pembelajaran Di Sekolah Dasar. Jakarta: Kencana Prenadamedia Group.

Sutikno, Sobry. (2013). Belajar dan Pembelajaran. Lombok: Holistica

Trianto. (2014). Mendesain Model Pembelajaran Inovatif Progresif. Jakarta: Kencana.

Zulfah Hasana. (2013) Pengaruh Model Pembelajaran TPS (Think-Pair-Share) dengan Metode Eksperimen Terhadap Hasil Belajar dan Sikap Ilmiah Siswa Kelas VII SMPN 10 Jember. Skripsi UNEJ 